\title{
Meta-Analysis of P73 Polymorphism and Risk of Non-Small Cell Lung
} Cancer

\author{
Xiangsong Cheng, Haiyang Liu, Yongan Song, Yunxia An, Weixia Xuan, Zheng Wang, Zhiwei xu, Nan Wei and Xiaoju Zhang* \\ Department of Respiratory and Critical Care Medicine, The People's Hospital of Zhengzhou University, Henan, China
}

\begin{abstract}
Background: The relationship between $p 73$ gene G4C14-to-A4T14 polymorphism and non-small cell lung cancer risk is unclear. Now we performed a meta-analysis to clarify the association of p73 polymorphism with nonsmall cell lung cancer.

Methods: To assess the association between p73 polymorphism and non-small cell lung cancer deeply, we searched Pubmed, Embase, CNKI, Wanfang and CBM databases. All analyses were done using RevMan 5.3 software which provided by the Cochrane Collaboration and Stata version 12.0. The statistical heterogeneity among studies was assessed with the chi-square-based $Q$ test. We used the random effects model as well as the fixed effects model to calculate the pooled ORs.
\end{abstract}

Results: Our meta-analysis included 6 studies with a total of 1658 patients with non-small lung cancer and 2328 cancer-free control subjects. In all comparisons, we find none of genetic models shows significant relation with the risk of non-small lung cancer (recessive model: OR: 1.16, 95\% Cl: 0.94-1.43; dominant model: OR: $0.63,95 \% \mathrm{Cl}$ : 0.37-1.06; co-dominant model: OR: 1.63, 95\%Cl: 0.94-2.83; allelic model: OR: 1.20, 95\%Cl: 0.98-1.48). However, when we proceeded to subgroup analysis according country, significantly increased risk was observed in a recessive models (OR: $1.35,95 \% \mathrm{Cl}: 1.15-1.59$ ), in a co-dominant model: (OR: $2.49,95 \% \mathrm{Cl}: 1.76-3.53$ ), in an allelic model $(\mathrm{OR}, 1.41,95 \% \mathrm{Cl}, 1.24-1.61)$. Significantly decreased risk was observed in a dominant model $(\mathrm{OR}: 0.42,95 \% \mathrm{Cl}$ : 0.30-0.59).

Conclusions: Our results indicate that $p 73$ gene G4C14-to-A4T14 polymorphism is associated with the risk of non-small cell lung cancer in China. However, a large gene-to-environment research is required to confirm this conclusion.

Keywords: p73 polymorphism; Non-small cell lung cancer; Meta analysis

\section{Background}

Non-small lung cancer (NSCLC) was a subtype for lung cancer, one of the most common malignancies of the world, especially in male [1]. The incidence of NSCLC is largely affected by tobacco smoking. However, not every NSCLC patient has the smoking history [2,3]. As we all know, genetic factors play an important role in lung cancer. The different individual genetic susceptibility to tumor [4-6]. Therefore, the research of genetic variants related to NSCLC may contribute to forecasting an individual's risk of suffering from this disease. Recently, p73 gene is identified a significant gene of tumorigenesis and lots of studies have demonstrated that the $p 73$ gene have a pivotal role in the occurrence of various types of cancer, including lung cancer [7-10]. However, there are very few reports of literature about NSCLC, and the results are not conclusive. Akio found p73 polymorphism was related with the decreased risk of NSCLC in Japanese population [11]. However, Wang found the opposite conclusion [12]. Therefore, to further explore the relationship between p73 polymorphism and NSCLC, we utilized a meta-analysis including data from all eligible case-control studies to summarize the currently published data.

\section{Methods}

Literatures collection and screening We searched several databases including the Pubmed, Embase, CNKI (China National Knowledge Infrastructure), Wanfang database and Chinese Biomedicine databases for all articles on the relation between p73 G4C14-A4T14 polymorphism and risk of non-small lung cancer (last search update $10^{\text {th }}$ August 2017) by using keywords of 'p73', 'polymorphism', 'polymorphisms' and 'lung cancer' without any restriction on language or publication year. We also searched the other publications of references quoted in review and related meta-analysis by hand. The inclusion and exclusion criteria of literatures Studies would be considered for inclusion if:

1. Independently published case-control or cohort studies where the relation between p73 G4C14-to-A4T14 polymorphism and NSCLC susceptibility was investigated;

2. The publication published available genotype data for odds ratio $(\mathrm{OR})$ or relative risk $(\mathrm{RR})$ values and $95 \% \mathrm{CI}$ (confidence interval) estimation and

3. If several studies were published on the basis of the same case population, we selected the most recent or the largest study.

The major exclusion criteria were:

1. Duplicate data,

2. There is not available relevant data

3. In the control population there is heterogeneity of gene polymorphism.

${ }^{*}$ Corresponding author: Xiaoju Zhang, Department of Respiratory and Critical Care Medicine, The People's Hospital of Zhengzhou University, Henan, China, Tel: 8687160159; E-mail: zhangxiaoju1010@henu.edu.cn

Received February 02, 2018; Accepted February 07, 2018; Published February 13,2018

Citation: Cheng X, Liu H, Song Y, An Y, Xuan W, et al. (2018) Meta-Analysis of P73 Polymorphism and Risk of Non-Small Cell Lung Cancer. J Pulm Respir Med 8: 445. doi: 10.4172/2161-105X.1000445

Copyright: @ 2018 Cheng X, et al. This is an open-access article distributed under the terms of the Creative Commons Attribution License, which permits unrestricted use, distribution, and reproduction in any medium, provided the original author and source are credited. 


\section{Quality assessment and data extraction}

Two investigators extracted information from all eligible publication independently according to the inclusion criteria. Any disagreement was coordinated by referring to a third investigator. We assessed the methodological quality of the included studies with the Cochrane Handbook 5.2 quality evaluation criteria. The essential information from various studies included publication year, the first author, ethnicity, and country, sample size of cases and controls and genotype frequency for the present polymorphism.

\section{Statistical analysis}

All analyses were done using RevMan 5.3 software and Stata version 12.0. A statistical significance was considered when $\mathrm{P}<0.05$. Assessment of the relation between p73 G4C14-to-A4T14 polymorphism and NSCLC susceptibility was performed by calculating ORs with $95 \%$ CIs. The pooled ORs were performed for allele model (AT vs. GC), the homozygote genotypes (AT/AT vs. GC/GC), the heterozygote genotypes (AT/GC vs. GC/GC), the dominant model(AT/AT+AT/ GC vs. GC/GC), and the recessive model (AT/AT vs. AT/GC+GC/ GC). Subgroup analysis was conducted by different countries. The statistical heterogeneity among studies was assessed with the chisquare-based $\mathrm{Q}$ test $(\mathrm{P}<0.10$ was considered significant $)$ [13]. If there was no obvious heterogeneity, the fixed-effects model derived from the Mantel-Haenszel method was used to estimate the summary OR [14]; otherwise, the random-effects model using the DerSimonian and Laird method was used [15]. Using the Pearson chi-square test, we checked the Hardy-Weinberg equilibrium (HWE) for the controls of all studies. Besides, we performed sensitivity analysis to check if any single data had a greater impact on the overall conclusion. Funnel plots was applied to diagnose the potential publication bias [16].

\section{Results}

\section{Study identification}

As shown in Figure 1, 47 English literatures were reviewed through database searching. A total of thirty seven literatures were excluded because of different gene/SNP/cancer, duplicate publication and review or meta-analysis. Six literatures were excluded because of unavailable genotype data. Finally, a total of 6 literatures [11,12,17-21] were included in the analysis with a total of 1658 patients with NSCLC and 2328 control subjects. Features included in this literature were shown in Table 1.

\section{Quantitative synthesis}

The main result of meta-analysis and heterogeneity are present in Figures 2 and 3 . As significant heterogeneity was detected, we used the random effects model as well as the fixed effects model to calculate the pooled ORs. In overall comparisons, none of genetic models showed significant association with the risk of non-small lung cancer (recessive model: OR: 1.16, 95\%CI: 0.94-1.43; dominant model: OR: 0.63, 95\%CI: 0.37-1.06; co-dominant model: OR: 1.63 , 95\%CI: 0.94-2.83; allelic model: OR: 1.20, 95\%CI: 0.98-1.48) (Figure 2). However, when we proceeded to subgroup analysis according country, significantly increased risk was observed in a recessive models (OR: 1.35, 95\% CI: 1.15-1.59), in a co-dominant model: (OR: $2.49,95 \%$ CI: $1.76-3.53$ ), in a allelic model (OR: 1.41, 95\%CI: 1.24-1.61). Significantly decreased risk was observed in a dominant model (OR: 0.42, 95\%CI: 0.30-0.59) (Figure 3).

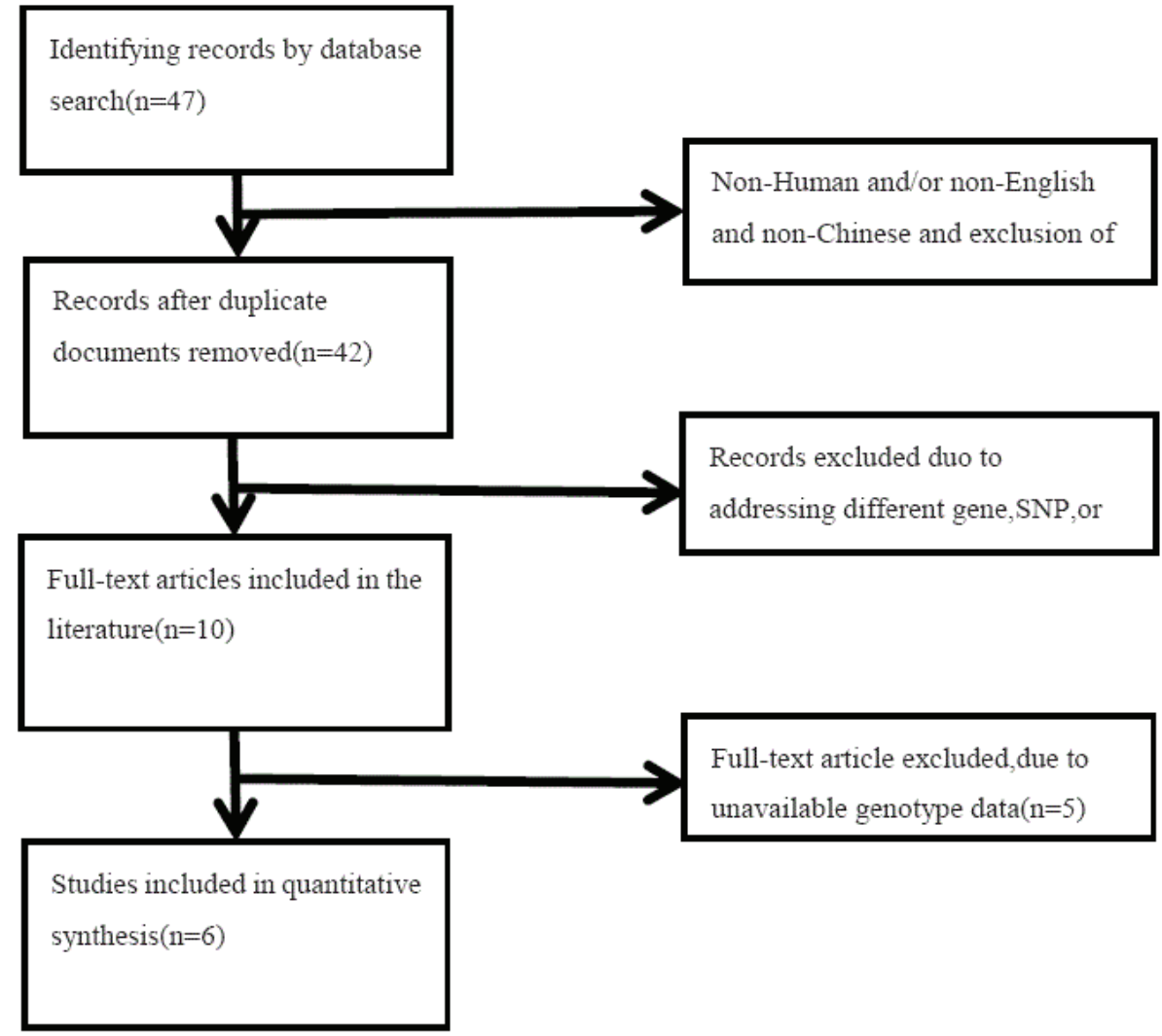

Figure 1: Flow chart of literature search and research selection 
Citation: Cheng X, Liu H, Song Y, An Y, Xuan W, et al. (2018) Meta-Analysis of P73 Polymorphism and Risk of Non-Small Cell Lung Cancer. J Pulm Respir Med 8: 446. doi: 10.4172/2161-105X.1000446

Page 3 of 7

\begin{tabular}{|c|c|c|c|c|c|c|c|}
\hline \multirow{2}{*}{ Authors } & \multirow{2}{*}{ Publication year } & \multirow{2}{*}{ Country } & \multirow{2}{*}{ Ethnicity } & \multicolumn{3}{|c|}{ Genotype(case/control) } & \multirow{2}{*}{$\begin{array}{c}\text { HWE } \\
\text { YES }\end{array}$} \\
\hline & & & & GC/GC & GC/AT & AT/AT & \\
\hline Akio [11] & 2003 & Japanese & Asian & $109 / 130$ & $68 / 95$ & $12 / 10$ & 0.215 \\
\hline Wang [12] & 2014 & China & Asian & $87 / 102$ & $57 / 68$ & $8 / 25$ & 0.24 \\
\hline Jun [17] & 2007 & Korea & Asian & $266 / 338$ & $184 / 212$ & $35 / 32$ & 0.87 \\
\hline Wang [18] & 2015 & China & Asian & $108 / 104$ & $68 / 68$ & $10 / 26$ & YES \\
\hline Wu [19] & 2017 & China & Asian & $294 / 490$ & $149 / 361$ & $17 / 71$ & 0.691 \\
\hline Wen [20] & 2017 & China & Asian & $94 / 98$ & $80 / 71$ & $12 / 27$ & NO \\
\hline
\end{tabular}

Table 1: Characteristics of incorporated studies.

A

\begin{tabular}{|c|c|c|c|c|c|c|c|c|c|c|}
\hline Study or Subqroup & $\begin{array}{l}\text { Cas } \\
\text { Events }\end{array}$ & Total & $\begin{array}{l}\text { Contr } \\
\text { Events }\end{array}$ & $\begin{array}{l}\text { ol } \\
\text { Total }\end{array}$ & Weight & $\begin{array}{c}\text { Odds Ratio } \\
\text { M-H, Random, } 95 \% \mathrm{Cl}\end{array}$ & & $\begin{array}{r}\text { Odds } \\
\text { M-H, Rando }\end{array}$ & $\begin{array}{l}\text { Ratio } \\
\text { om, } 95 \% \mathrm{Cl}\end{array}$ & \\
\hline Akio2003 & 109 & 189 & 130 & 235 & $14.9 \%$ & $1.10[0.75,1.62]$ & & & & \\
\hline Jun2007 & 266 & 485 & 338 & 582 & $21.3 \%$ & $0.88[0.69,1.12]$ & & & & \\
\hline Wang2014 & 87 & 152 & 102 & 195 & $13.4 \%$ & $1.22[0.80,1.87]$ & & & & \\
\hline WANG2015 & 108 & 186 & 104 & 198 & $14.2 \%$ & $1.25[0.84,1.87]$ & & & & \\
\hline WU2017 & 294 & 460 & 490 & 922 & $21.9 \%$ & $1.56[1.24,1.97]$ & & & & \\
\hline Wen2017 & 94 & 186 & 98 & 196 & $14.3 \%$ & $1.02[0.68,1.53]$ & & & & \\
\hline Total $(95 \% \mathrm{Cl})$ & & 1658 & & 2328 & $100.0 \%$ & $1.16[0.94,1.43]$ & & & & \\
\hline Total events & 958 & & 1262 & & & & & & & \\
\hline $\begin{array}{l}\text { Heterogeneity: Tau } \\
\text { Test for overall effec }\end{array}$ & $\begin{array}{l}0.04 ; \mathrm{Chi} \\
\mathrm{Z}=1.35\end{array}$ & $\begin{array}{l}I^{2}=12.1 \\
(P=0.1\end{array}$ & $3, d f=5$ & $(P=0$. & $03) ;\left.\right|^{2}=59$ & & 0.5 & $\begin{array}{c}0.7 \\
\text { Favours [case] }\end{array}$ & $\begin{array}{c}1.5 \\
\text { Favours [control] }\end{array}$ & 2 \\
\hline
\end{tabular}

B

\begin{tabular}{|c|c|c|c|c|c|c|c|c|c|c|}
\hline Study or Subqroup & $\begin{array}{l}\text { Case } \\
\text { Events }\end{array}$ & Total & $\begin{array}{l}\text { Contr } \\
\text { Events }\end{array}$ & $\begin{array}{l}\text { rol } \\
\text { Total } \\
\text { Tol }\end{array}$ & Weight & $\begin{array}{l}\text { Odds Ratio } \\
\mathrm{M}-\mathrm{H}, \text { Random, } 95 \% \mathrm{Cl}\end{array}$ & & $\begin{array}{r}\text { Odds } \\
\text { M-H, Rand }\end{array}$ & $\begin{array}{l}\text { s Ratio } \\
\text { dom, } 95 \% \mathrm{Cl}\end{array}$ & \\
\hline Akio2003 & 12 & 189 & 10 & 235 & $14.5 \%$ & $1.53[0.64,3.61]$ & & & $T=$ & \\
\hline Jun2007 & 35 & 485 & 32 & 582 & $19.5 \%$ & $1.34[0.81,2.19]$ & & & & \\
\hline Wang2014 & 8 & 152 & 25 & 195 & $14.9 \%$ & $0.38[0.17,0.86]$ & & & & \\
\hline WANG2015 & 10 & 186 & 26 & 198 & $15.8 \%$ & $0.38[0.18,0.80]$ & & & & \\
\hline Wu2017 & 17 & 460 & 71 & 922 & $18.8 \%$ & $0.46[0.27,0.79]$ & & & & \\
\hline Wen2017 & 12 & 186 & 27 & 196 & $16.5 \%$ & $0.43[0.21,0.88]$ & & & & \\
\hline Total $(95 \% \mathrm{Cl})$ & & 1658 & & 2328 & $100.0 \%$ & $0.63[0.37,1.06]$ & & & & \\
\hline Total events & 94 & & 191 & & & & & & & \\
\hline \multicolumn{7}{|c|}{$\begin{array}{l}\text { Heterogeneity: } \text { Tau }^{2}=0.31 ; C \mathrm{Ch}^{2}=18.41, \mathrm{df}=5(\mathrm{P}=0.002) ; \mathrm{I}^{2}=73 \% \\
\text { Test for overall effect: } Z=1.73(\mathrm{P}=0.08)\end{array}$} & 0.1 & $\begin{array}{ll}0.2 & 0.5 \\
\text { Favours [Case] }\end{array}$ & $1 \frac{1}{2}$ & $\begin{array}{cc}5 & 1 \\
\text { control] }\end{array}$ \\
\hline
\end{tabular}

C

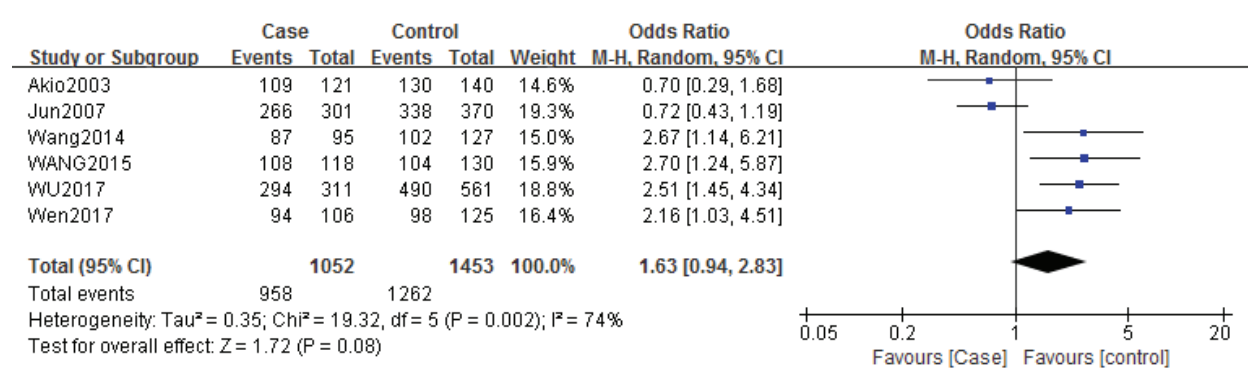

D

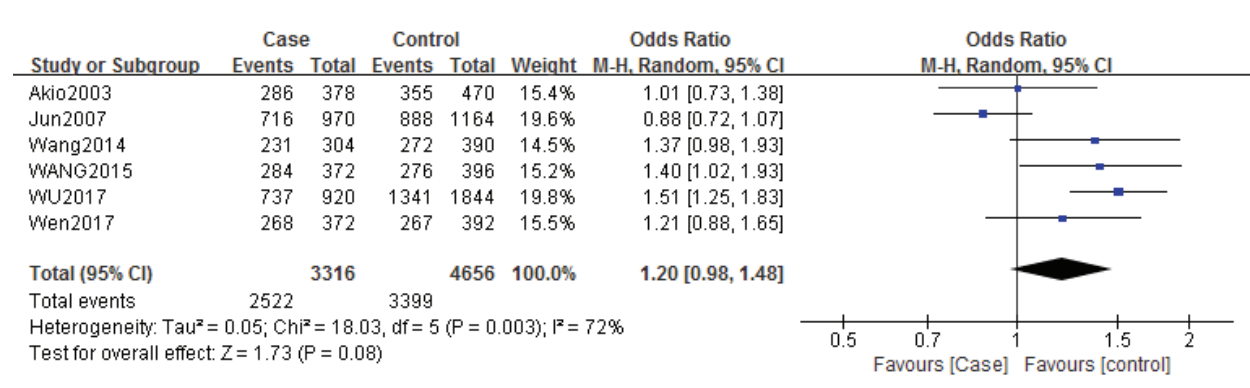

Figure 2: Meta-analysis of genetic polymorphism and non-small lung cancer. (A) Recessive model; (B) Dominant model; (C) Co-dominat model; (D) Allelic model. 
Citation: Cheng X, Liu H, Song Y, An Y, Xuan W, et al. (2018) Meta-Analysis of P73 Polymorphism and Risk of Non-Small Cell Lung Cancer. J Pulm Respir Med 8: 446. doi: 10.4172/2161-105X.1000446

$\mathbf{A}$

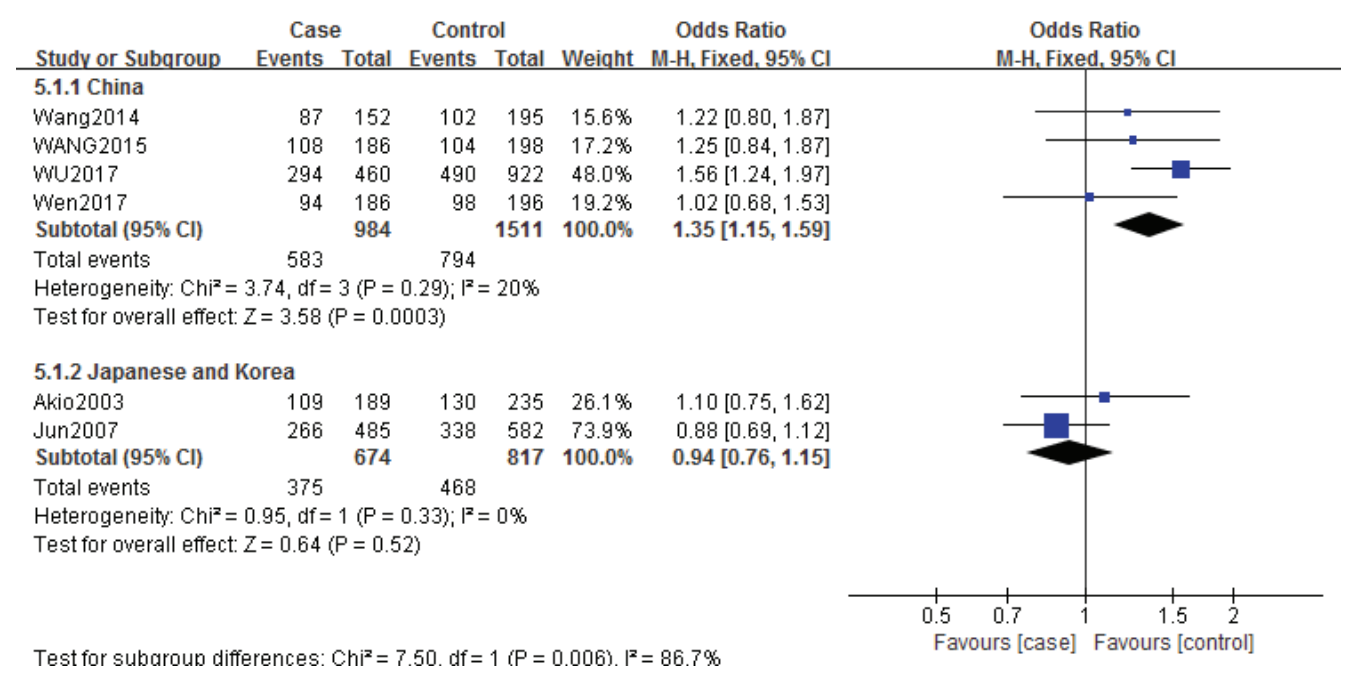

B

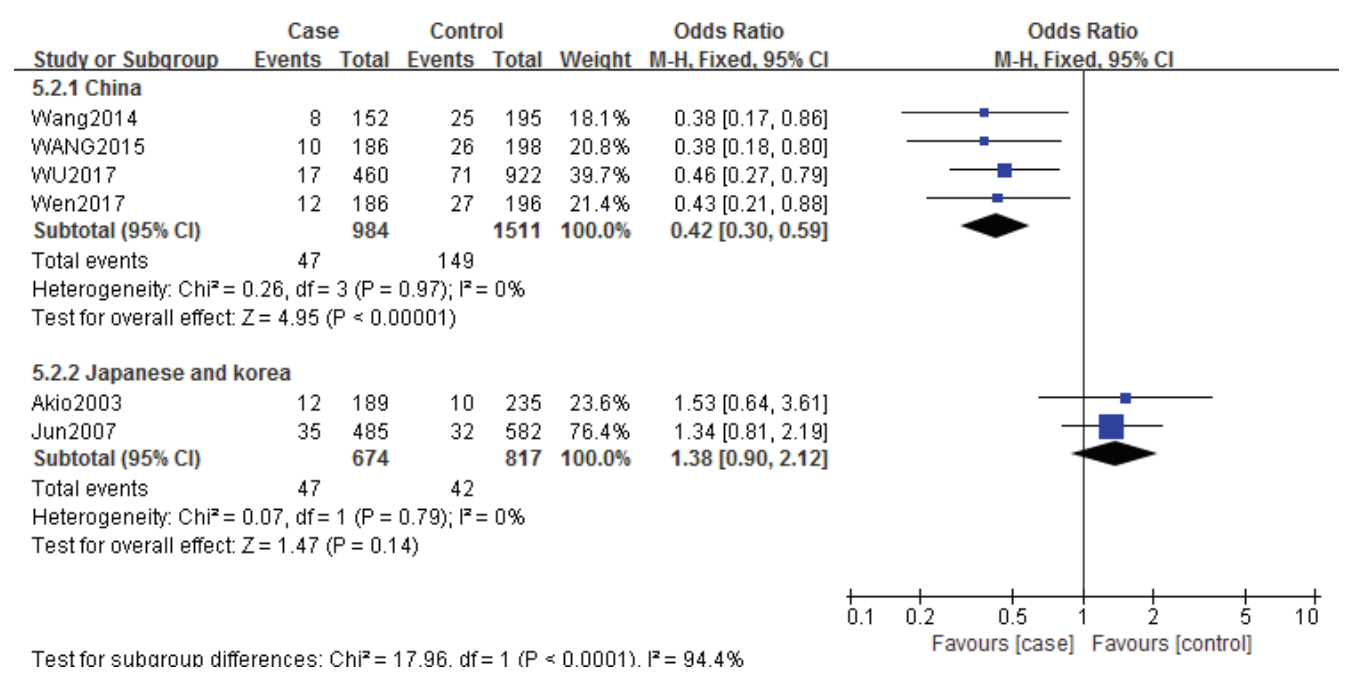

C

Case Control Odds Ratio Odds Ratio

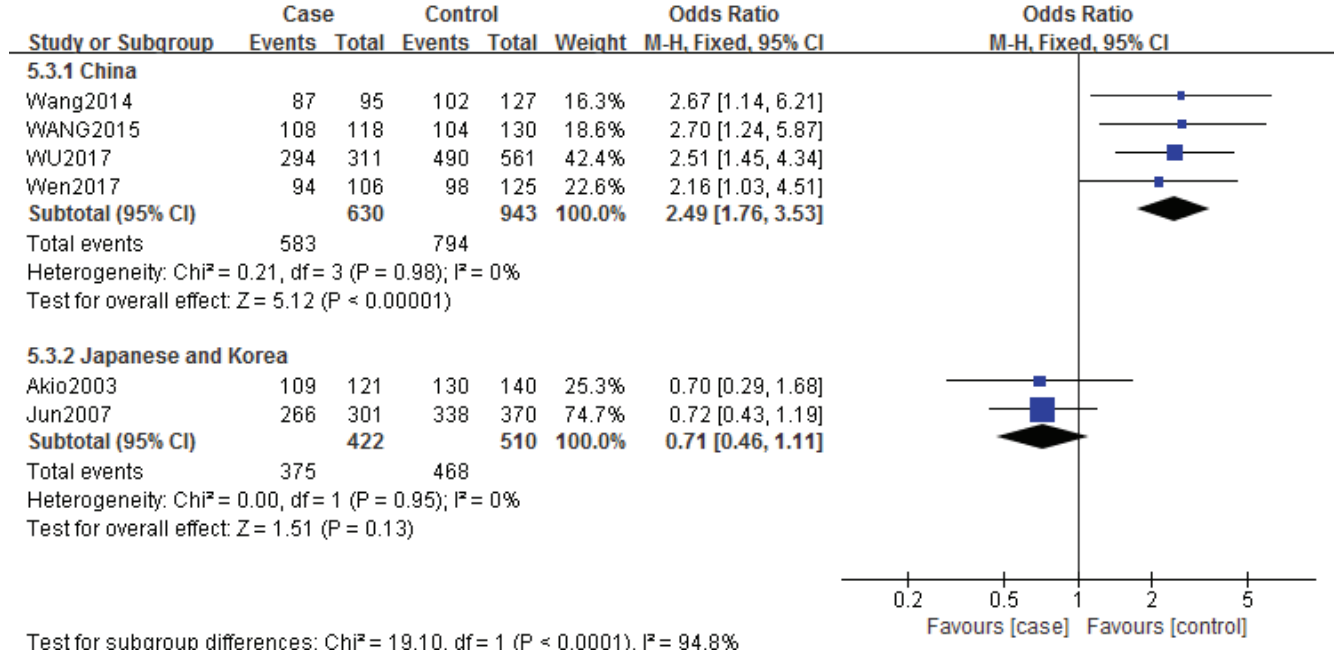


D

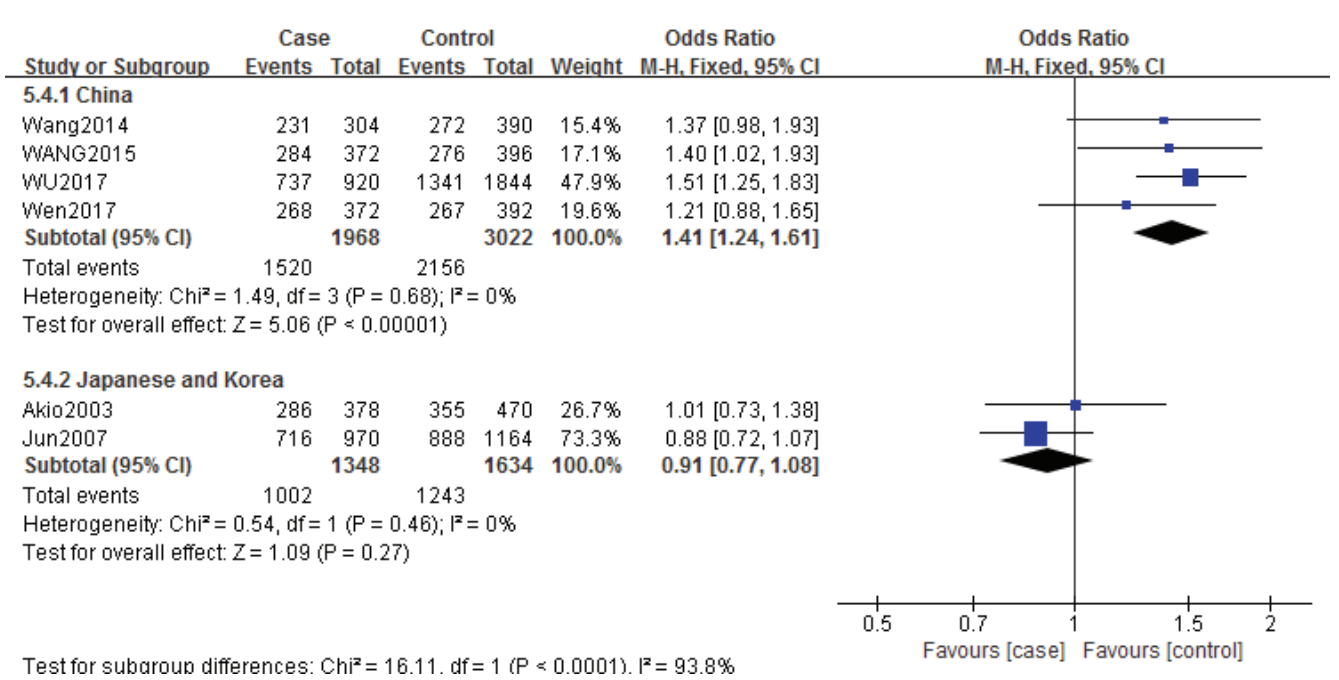

Figure 3: Subgroup analysis by country. (A) Recessive model; (B) Dominant model; (C) Co-dominat model; (D) Allelic model.

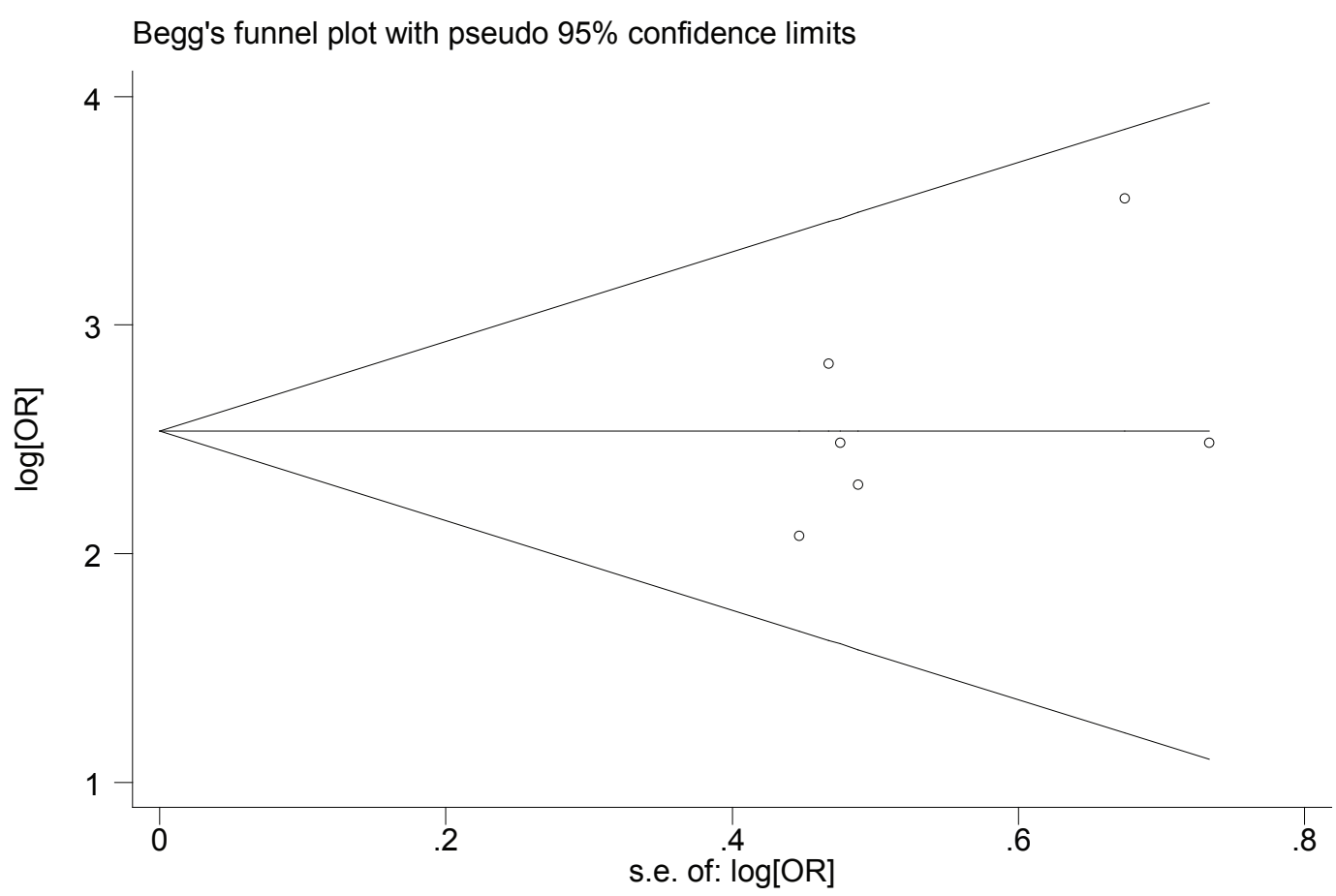

Figure 4: Begg's funnel plot for Publication bias test for all included studies (GC/AT+AT/AT vs. GC/GC).

\section{Publication bias analysis}

As depicted in Figure 4 (the dominant model), the funnel plot showed no evidence for obvious asymmetry. We used the Egger's test to further quantitatively estimate the publication bias, the result indicated no existence of significant publication bias $(\mathrm{P}=0.273)$. This indicated that in the present study there is no publication bias, and the result is credible.

\section{Discussion}

In this study, we performed a meta-analysis to clarify the relation between p73 polymorphism and non-small cell lung cancer. We found significant association of p73 polymorphism with non-small cell lung cancer in a recessive, dominant, co-dominant and allelic model in Chinese population but not in Japanese and Korean. The $p 73$ gene was identified at chromosome 1p36.33 in 1977 [21], a site which had 
been proved to commonly undergo loss of heterozygosity (LOH) in various kinds of cancer [21-23]. In addition, LOH had been reported to occur in $62 \%$ of lung cancer patients at the $p 73$ gene [24], indicating that in the development of lung cancer $p 73$ gene probably play an important role $[25,26]$. Two completely linked single-nucleotide polymorphisms (SNPs) at position $4(\mathrm{G} \rightarrow \mathrm{A})$ and $(\mathrm{C} \rightarrow \mathrm{T})$ (designated as G4C14-to-A4T14, rs numbers 2273953 and 1801173) in intron 1 of the $p 73$ gene have been certified to be related to the lung cancer risk $[27,5]$. Only three genotypes are possible: GC/GC, GC/AT and AT/AT, because these SNPs are in complete linage equilibrium. The association between polymorphism in previous studies and the development of various types of cancer risk have been reported. Studies have found that carriers with AT allele genotype have significantly increased risk of lung cancer than GC/GC genotype in the north of China [28] and nonHispanic whites [29]. Another study found no significant relationship between the G4C14-to-A4T14 polymorphism and the risk of lung cancer in Korea [30] and Japan [31]. Otherwise, another study found that crowd with AT allele genotype has reduced risk of lung cancer in Chinese [32]. Liu's meta-analysis suggested that p73 G4C14-toA4T14 polymorphism may play a important role in development of lung cancer in Caucasians [33]. However, all the above articles did not classify lung cancer by pathology. Above all, association between p73 polymorphism and NSCLC was not clear. The present study has shown that significant association of p73 polymorphism with non-small cell lung cancer in a recessive, dominant, co-dominant and allelic model in Chinese population but not in Japanese and Korean. However, further research and screening of etiological relations between the functional polymorphism loci of $p 73$ gene and the susceptibility of NSCLC is still needed. Some limitation of this meta-analysis should be addressed. Firstly, the total number of cases and controls was somewhat small to detect the potential exist of marginal effect. Therefore, more studies with larger sample size and providing more detail information are needed. Secondly, there was significant between-study heterogeneity from studies of $\mathrm{p} 73$ polymorphism, and the genotype distribution also showed deviation from HWE in some studies. Finally, potential publication bias may exist in this meta-analysis, as studies with negative results are more likely not to be published.

\section{Conclusion}

In conclusion, based on the combined data, this meta-analysis demonstrated that there was no clear association between p73 G4C14to-A4T14 polymorphism and overall non-small lung cancer risk, but we observed increased risk of lung cancer in Chinese population.

\section{Funding}

This work was supported by Science and Technology Office of Henan province. The project name: Preparation and Screening and the Role in EMT of N-Cadherin, CD146. The project number: 154100510021.

\section{Acknowledgements}

The authors acknowledge Professor Yuanlin Song for his assistance in performing chart review.

\section{References}

1. Jemal A, Bray F, Center M (2011) Global cancer statistics. Cancer J Clin 61: 69-90.

2. Spitz MR (2001) Genetic susceptibility to lung cancer: The role of DNA damage and repair. Cancer Epidemiol Biomarkers Prev 126: 89-98.

3. Lam WK,White NW, Chan-Yeung MM (2004) Lung cancer epidemiology and risk factors in Asia and Africa. Int J Tuberc Lung Dis 8: 1045-1057.

4. Zhou BBS, Elledge SJ (2000) The DNA damage response: Putting checkpoints in perspective. Nature 408: 433-439.
5. $\mathrm{Hu} \mathrm{Z}$ Miao X, Ma H (2005) Dinucleotide polymorphism of p73 gene is associated with a reduced risk of lung cancer in a Chinese population. Int $J$ Cancer 114: 455-460.

6. Cheng Z, Wang W, Song YN (2012) hOGG1, p53 genes, and smoking interactions are associated with the development of lung cancer. Asian Pac J Cancer Prev 13: 1803-1808.

7. Uramoto H, Sugio K, Oyama $\mathrm{T}$ (2006) Expression of the p53 family in lung cancer. Anticancer Res 26: 1785-1790.

8. Liu K, Zhan M, Zheng $P$ (2008) Loss of p73 expression in six non-small cel lung cancer cell lines is associated with $5^{\prime} \mathrm{CpG}$ island methylation. Exp Mol Pathol 84: 59-63.

9. lacono ML, Monica V, Saviozzi S (2011) p63 and p73 isoform expression in non-small cell lung cancer and corresponding morphological normal lung tissue. J Thorac Oncol 6: 473-481.

10. Nyman U, Sobczak-Pluta A, Vlachos $P(2005)$ Full-length p73a represses druginduced apoptosis in small cell lung carcinoma cells. J Biol Chem 280: 3415934169.

11. Hiraki A, Matsuo K, Hamajima N (2003) Different risk relations with smoking for non-small-cell lung cancer: Comparison of TP53 and TP73 genotypes. Asian Pac J Cancer Prev 4:107-112.

12. Ma WL,Tang JX (2014) Association between a p73 gene polymorphism and genetic susceptibility to non-small cell lung cancer in the south of China. Asian Pac J Cancer Prev 15: 10387-10391.

13. Higgins J, Thompson SG (2002) Quantifying heterogeneity in a meta-analysis. Stat Med 21: 1539-1558.

14. Mantel N, Haenszel W (1959) Statistical aspects of the analysis of data from retrospective studies of disease. J National Cancer Ins 22: 719-748.

15. Der Simonian R, Laird N (1986) Meta-analysis in clinical trials. Control Clin Trial 7:177-188.

16. Egger M, Smith GD, Schneider M (1997) Bias in meta-analysis detected by a simple, graphical test. Bmj 315: 629-634.

17. Jun H J, Park SH, Lee WK (2007) Combined effects of p73 and MDM2 polymorphisms on the risk of lung cancer. Molecular carcinogenesis 46: 100105

18. Wang SS, Zhu XQ, Yang SD (2015) Association of p73 G4C14-to-A4T14 polymorphism with non-small cell lung cancer risk. Oncol Lett 10: 995-999.

19. Wu Q, Shi Y, Ge L (2017) Relationship of p73 gene polymorphism and additional gene-smoking and gene-obesity interaction with non-small cell lung cancer risk. Oncotarget 8: 34423

20. Li W, Wang SS, Deng J (2017) Association of p73 gene G4C14-A4T14 polymorphism and MDM2 gene SNP309 with non-small cell lung cancer risk in a Chinese population. Oncol Lett 14: 1817-1822.

21. Kaghad M, Bonnet $H$, Yang A (1997) Monoallelically expressed gene related to p53 at Ip36,a region frequently deleted in neuro-blastoma and other human cancers. Cell 90: 809-819.

22. Bénard J, Douc-Rasy S, Ahomadegbe JC (2003) TP53 family members and human cancers. Human mutation 21: 182-191

23. Moll UM, Erster S, Zaika A (2001) p53, p63 and p73-solos, alliances and feuds among family members. Biochimica et Biophysica Acta 1552: 47-59.

24. Shibukawa K, Miyokawa N, Tokusashi Y (2009) High incidence of chromosomal abnormalities at $1 \mathrm{p} 36$ and $9 \mathrm{p} 21$ in early-stage central type squamous cell carcinoma and squamous dysplasia of bronchus detected by autofluorescence bronchoscopy. Oncol Rep 22: 81-87.

25. Mai M,Yokomizo A, Qian C (1998) Activation of p73 silent allel in lung cancer Cancer Res 58: 2347-2349

26. Tokuchi Y, Hashimoto T, Kobayashi $Y$ (1999) The expression of p73 is increased in lung cancer,independent of p53 gene alteration. British $\mathrm{J}$ Cancer 80:1623.

27. Li G, Wang LE, Chamberlain RM (2004) p73 G4C14-to-A4T14 polymorphism and risk of lung cancer. Cancer research 64: 6863-6866.

28. Zhang X, Li X, Wu Z (2013) The p73 G4C14-to-A4T14 polymorphism is associated with risk of lung cancer in the Han nationality of North China. Mol Carcinogenesis 52: 387-391. 
Citation: Cheng X, Liu H, Song Y, An Y, Xuan W, et al. (2018) Meta-Analysis of P73 Polymorphism and Risk of Non-Small Cell Lung Cancer. J Pulm Respir Med 8: 446. doi: 10.4172/2161-105X.1000446

29. Li Q, Athan ES, Wei M (2004) TP73 allelic expression in human brain and allele frequencies in Alzheimer's disease. BMC Med Genet 5: 14

30. Choi JE, Kang HG, Chae MH (2006) No association between p73 G4C14to-A4T14 polymorphism and the risk of lung cancer in a Korean population. Biochem Genet 44: 533-540.

31. Huang XE, Hamajima N, Katsuda N, Matsuo K, Hirose K, et al. (2003) Association of p53 codon Arg72Pro and p73 G4C14-to-A4T14 at exon 2 genetic polymorphisms with the risk of Japanese breast cancer. Breast Cancer 10: 307-311.

32. Hu ZB, Wang YG, Ma HX (2005) Association of two exonic genetic polymorphisms in the DNA repair gene XPC with risk of lung cancer in Chinese population. Chinese J Med Genet 22: 415.

33. Liu H, Liang Y, Liao H (2014) Association of p73 G4C14-to-A4T14 polymorphism with lung cancer risk. Tumor Biology 35: 9311-9316. 